\title{
PENERAPAN MODEL PEMBELAJARAN TEAM ASSISTED INDIVIDUALIZATION (TAI) DAN TEAMS GAME TOURNAMENTS (TGT) PADA MATERI LINGKARAN DITINJAU DARI GAYA BELAJAR SISWA SMP DI KABUPATEN WONOGIRI
}

\author{
Yustinus Murdoko ${ }^{1}$, Mardiyana ${ }^{2}$, dan Budi Usodo ${ }^{3}$ \\ ${ }^{1,2,3}$ Prodi Magister Pendidikan Matematika, FKIP Universitas Sebelas Maret Surakarta
}

\begin{abstract}
The aim of the research was to determine the effect of learning models on mathematics achievement viewed from the student learning style. The learning models compared were TAI (Team Assisted Individualization), TGT (Teams Games tournament) and direct teaching learning. The type of the research was quasiexperimental research. The population was the students of junior high school in Wonogiri regency on academic year 2013/2014. The size of sample was 234 students consisted of 77 students in the first experimental group, 76 students on the second experimenta groupl, and 81 students on the tirth experimental group. The instruments used were mathematics achievement test, questioner, and the likert scale instrument. The data was analyzed using analisis of variance two way. Conclusions of the research were as follow. (1) the learning achievement of the students instructed with the TAI learning model is the same as that of the students instructed with the TGT learning model, and the learning achievements of the students instructed with the TAI learning model and that of the students instructed with the TGT learning model are better than that of the students instructed with the direct learning model; (1) the learning achievement of the students instructed with the TAI learning model is the same as that of the students instructed with the TGT learning model, and the learning achievements of the students instructed with the TAI learning model and that of the students instructed with the TGT learning model are better than that of the students instructed with the direct learning model; (2) the students with the visual, auditory, and kinesthetic styles have the same learning achievement in Mathematics; (3) in each learning model, the students with the visual, auditory, and kinesthetic learning styles have the same learning achievement in Mathematics; and (4) in each learning style, the learning achievement of the students instructed with the TAI learning model is the same as that of the students instructed with the TGT learning model, and the learning achievement of the students instructed with the TAI learning model and that of the students instructed with the TGT learning model are better than that of the students instructed with the direct learning model.
\end{abstract}

Keywords: TAI, TGT, direct learning, learning style, achievement

\section{PENDAHULUAN}

Pencapaian bidang matematika siswa Indonesia pada PISA 2012 masih belum memuaskan. Hasil Programme for International student Assesment 2012, Indonesia berada di peringkat ke-64 dari 65 negara yang berpartisipasi dengan skor rata-rata 375 (Sumber : Kompas cetak, 5 Desember 2013). Demikian pula keadaan yang terjadi di berbagai daerah di Indonesia, pencapaian bidang matematika masih belum memuaskan. Ini juga terjadi di kabupaten Wonogiri yang juga mendapatkan hasil yang tidak begitu baik dalam pencapaian bidang matematika. Rata-rata nilai matematika UN tahun 2013 kabupaten Wonogiri adalah 4,93. 
Materi lingkaran merupakan materi dengan prosentase penguasaan materi yang cukup rendah, hal ini terlihat pada kemampuan menyelesaikan masalah berkaitan dengan unsur-unsur/bagian-bagian lingkaran/hubungan dua lingkaran dengan persentase 35,19\% untuk kabupaten Wonogiri. (Sumber: PAMER Tahun Pelajaran 2012/2013)

Model pembelajaran kooperatif (cooperative learning) merupakan model pembelajaran dengan paham konstruktivisme dimana siswa membangun pengetahuannya sendiri di bawah bimbingan guru. Model pembelajaran ini merupakan rangkaian kegiatan berkelompok yang berbeda-beda, baik kemampuan tinggi, sedang, dan rendah yang penghargaannya lebih menekankan pada masing-masing kelompok. Terdapat berbagai macam tipe model pembelajaran kooperatif dengan berbagai karakteristiknya masingmasing. Model pembelajaran kooperatif yang dapat dipilih untuk materi lingkaran adalah TAI maupun TGT.

Gaya belajar anda adalah kunci untuk mengembangkan kinerja dalam pekerjaan, disekolah, dan dalam situasi-situasi antar pribadi (De Potter \& Hernacki. 140: 2012). Setiap siswa mempunyai karakteristik gaya belajar yang berbeda. Siswa yang lebih suka belajar melihat (visual) akan lebih suka jika diajar dengan menggunakan gambar atau grafik. Siswa yang lebih suka belajar melalui mendengar (auditorial) akan lebih suka jika diajar dengan menggunakan dengan menggunakan intonasi yang menarik. Siswa yang lebih suka belajar melalui praktik (kinestetik) akan lebih suka jika diajar dengan pembelajaran praktikum. Karakteristik siswa ini perlu diperhatikan guru untuk mencapai tujuan pembelajaran yang optimal. Akkoyunlu dan Soylu (2008) melakukan penelitian yang memberikan hasil bahwa siswa pada proses belajar berbeda sesuai dengan gaya belajar mereka. Selain itu, juga ditunjukkan bahwa tidak terdapat perbedaan yang signifikan antara tingkat prestasi siswa sesuai dengan gaya belajarnya pada pembelajaran menggunakan berbagai macam media. Tarim dan Akdeniz (2007) dalam penelitannya model pembelajaran TAI memberikan pengaruh yang lebih secara signifikan dibandingkan dengan model pembelajaran yang menggunakan model STAD. Van Wyk (2012) dalam penelitiannya menunjukkan pembelajaran dengan menggunakan TGT lebih memberikan skor prestasi yang lebih baik dari kelas kontrol.

Tujuan dari penelitian ini adalah untuk mengetahui : (1) Siswa yang memperoleh pembelajaran dengan model manakah mendapatkan prestasi lebih baik antara pembelajaran model TAI, pembelajaran model TGT atau pembelajaran langsung. (2) Siswa manakah yang memiliki prestasi lebih baik, antara siswa dengan gaya belajar visual, auditorial atau kinestetik. (3) Pada masing-masing model pembelajaran, manakah siswa yang memiliki prestasi yang lebih baik, antara siswa memiliki gaya belajar visual, 
auditorial atau kinestetik. (4) Pada masing-masing gaya belajar, manakah siswa yang memperoleh prestasi belajar yang lebih baik antara siswa yang mendapat pembelajaran dengan model pembelajaran TAI, model pembelajaran TGT atau pembelajaran langsung.

Pada penelitian ini dirumuskan hipotesis berikut : (1) Siswa yang mendapatkan pembelajaran dengan model TAI memperoleh prestasi yang sama dengan siswa yang mendapat pembelajaran dengan model TGT. siswa yang mendapat pembelajaran dengan model TAI dan TGT memperoleh prestasi yang lebih baik dari siswa yang mendapat pembelajaran langsung. (2) Siswa dengan gaya belajar visual dan auditori memiliki prestasi yang lebih baik dari siswa dengan gaya belajar kinestetik. Siswa dengan gaya belajar visual dan Auditorial memiliki prestasi belajar yang sama. (3) Pada pembelajaran dengan model TAI dan TGT siswa memiliki gaya belajar visual memiliki prestasi belajar yang sama dengan siswa memiliki gaya belajar auditori, dan kinestetik. Pada pembelajaran langsung siswa memiliki gaya belajar visual dan auditori memperoleh prestasi belajar yang lebih baik dari siswa memiliki gaya belajar kinestetik, dan siswa memiliki gaya belajar visual memperoleh prestasi belajar yang sama dengan siswa memiliki gaya belajar auditori, (4) Pada siswa dengan gaya belajar visual, auditori dan memperoleh pembelajaran dengan model TAI memiliki prestasi yang sama dengan yang memperoleh pembelajaran dengan model TGT, dan pembelajaran langsung. Pada siswa dengan gaya belajar kinestetik yang memperoleh pembelajaran dengan model TAI dan TGT akan memiliki prestasi yang lebih baik dari siswa yang memperoleh pembelajaran langsung, dan siswa yang memperoleh pembelajaran dengan model TAI dan TGT memiliki prestasi yang sama.

\section{METODE PENELITIAN}

Sebagai variabel bebas yang dapat menyebabkan berubahnya variabel terikat adalah model pembelajaran dan gaya belajar. Variabel terikat adalah prestasi belajar matematika. Populasi dalam penelitian ini adalah seluruh siswa kelas VIII SMP Negeri di Kabupaten Wonogiri Provinsi Jawa Tengah tahun pelajaran 2013/2014. Teknik pengambilan sampel dilakukan melalui sampling random stratifikasi berkelompok (stratified cluster random sampling), Dari tahapan proses pengambilan sampel diperoleh hasil sebagai berikut: Kelompok tinggi : SMP N 5 Wonogiri, Kelompok sedang: SMP N 3 Wonogiri, Kelompok rendah : SMP N 4 Pracimantoro. Teknik pengumpulan data dengan metode tes ini digunakan untuk mengumpulkan data tentang prestasi belajar matematika. Dalam penelitian ini bentuk tes yang digunakan adalah tes pilihan ganda dengan setiap jawaban benar mendapat skor 1, sedangkan setiap jawaban salah mendapat 
skor 0. Angket digunakan untuk memperoleh data mengenai gaya belajar siswa. Langkahlangkah penyusunan angket yaitu menentukan kisi-kisi angket, menentukan jenis dan bentuk angket, menyusun angket dan menetapkan skor angket.

Instrumen angket digunakan untuk mendapatkan data tentang gaya belajar siswa. Instrumen tes dignakan untuk mendapatkan tes prestasi belajar. Langkah selanjutnya adalah uji coba untuk validitas dan reliabilitas tes. Soal-soal tes disusun adalah soal-soal yang sifatnya masih sementara, sehingga diperlukan uji coba untuk validitas dan reliabilitas yang nantinya ditentukan layak tidaknya soal itu untuk digunakan. Tes diuji cobakan kepada siswa di sekolah dalam populasi yang tidak terpilih sebagai sampel. Analisis instrumen tes prestasi dilakukan dengan validitas isi dan uji reliabilitas, analisis butir dilakukan dengan uji daya pembeda, analisis tingkat kesukaran, dan validitas butir. Sedang pada instrumen angket dilakukan validitas isi, uji konsistesnsi internal, dan uji reliabilitas.

Teknik analisis data menggunakan analisis variansi dua jalan. Sebelum dilakukan analisis dilakukan terlebih dahulu uji keseimbangan dengan menggunakan analisis variansi satu jalan. Sebagai syarat analisis variansi di lakukan terlebih dahulu uji normalitas dan uji homogenitas. Uji normalitas menggunakan metode Lilliefors dan uji homogenitas dengan uji Bartlett dengan statistik uji Chi Kuadrat. Lebih kengkap rumus dapat dibaca dalam Budiyono (2009:168). Demikian pula dengan analisis variansi dua jalan terlebih dahulu dulakukan uji normalitas sebanyak 6 kali. Uji normalitas dilakukan pada kelompok menurut pembelajaran yaitu kelompok TAI, TGT dan langsung, sedangkan menurut gaya belajar adalah kelompok visual, ausitorial, dan kenestetik. Uji homogenitas dilakukan dua kali menurut kelompok Pembelajaran dan Gaya belajar. Setelah dilakukan uji prasyarat anava dilanjutkan dengan analisis variansi dua jalan sel tak sama. Apabila $\mathrm{H}_{0}$ ditolak maka perlu dilakukan uji lanjut pasca anava. Metode yang digunakan untuk uji lanjut anava dua jalan adalah metode Scheffe. Semua perhitungan di atas menggunakan microsoft Excel 2010.

\section{HASIL PENELITIAN DAN PEMBAHASAN}

Uji prasyarat anava satu jalan diperoleh bahwa kemampuan awal sampel TAI, TGT, dan pembelajaran langsung berasal dari populasi yang berdistribusi normal. Demikian pula dengan uji homogenitas diperoleh bahwa variansi kemampuan awal kelompok TAI, TGT, dan pembelajaran langsung memiliki variansi yang sama atau homogen. Dilanjutkan dengan anava satu jalan diperoleh kesimpulan bahwa rerata 
kemampuan awal dari kelompok TAI, TGT, dan pembelajaran langsung memiliki rerata yang sama. Artinya kemampuan awal sebelum dilakukan penelitian adalah sama.

Selanjutnya, dilakukan uji analisis variansi dua jalan sel tak sama pada data prestasi belajar. Rangkuman uji analisis variansi dua jalan sel tak sama disajikan pada Tabel 1. berikut.

Tabel 1. Rangkuman Analisis Variansi Dua Jalan Dengan Sel Tak Sama

\begin{tabular}{crccccc}
\hline Sumber & \multicolumn{1}{c}{$J K$} & $d k$ & $R K$ & $F_{\text {obs }}$ & $F_{\text {tabel }}$ & Kesimpulan \\
\hline A & 10877,10 & 2 & 5438,548 & 26,1655 & 3 & $\mathrm{H}_{0 \mathrm{~A}}$ ditolak \\
B & 200,89 & 2 & 100,4474 & 0,4833 & 3 & $\mathrm{H}_{0 \mathrm{~B}}$ diterima \\
AB & 497,53 & 4 & 124,3832 & 0,59842 & 2,37 & $\mathrm{H}_{0 \mathrm{AB}}$ diterima \\
Galat & 46766,72 & 225 & 207,8521 & - & - & - \\
Total & 58342,24 & 232 & - & - & - & - \\
\hline
\end{tabular}

Dari hasil perhitungan analisis variansi dua jalan dengan sel tak sama diperoleh nilai nilai $\mathrm{F}_{\mathrm{a}}=26,1655$ lebih besar dari $\mathrm{F}_{(0,05 ; 2 ; 224)}=3,00$. Oleh karena itu $\mathrm{H}_{0 \mathrm{~A}}$ ditolak, yang berarti terdapat perbedaan pengaruh antar masing-masing kategori model pembelajaran terhadap prestasi belajar siswa, sehingga terdapat perbedaan prestasi belajar yang signifikan antara siswa yang mendapat model pembelajaran kooperatif tipe TAI, model kooperatif tipe TGT, dan pembelajaran langsung. Pada perhitungan selanjutnya $H_{0 \mathrm{~B}}$ diterima karena nilai $F_{b}=0,483$ lebih kecil dari $F_{(0,05 ; 2 ; 24)}=3,00$ dan terletak di daerah kritis. Hal ini berarti tidak terdapat perbedaan prestasi belajar pada siswa gaya belajar visual, gaya belajar auditorial, dan gaya belajar. Pada perhitungan selanjutnya $H_{0 \mathrm{AB}}$ diterima karena nilai $F_{a b}=0,881$ kurang dari $F_{(0,05 ; 4 ; 275)}=2,37$ dan tidak terletak di daerah kritis. Hal ini berarti tidak terdapat interaksi antara model pembelajaran dan kategori gaya belajar siswa terhadap prestasi belajar.

Tabel 2. Rerata Masing-masing Sel

\begin{tabular}{ccccc}
\hline \multirow{2}{*}{ Model pembelajaran } & \multicolumn{3}{c}{ Gaya Belajar } & \multirow{2}{*}{ Rerata Marginal } \\
& Visual & Auditorial & Kinestetik & \\
\hline TAI & 70,30 & 75,17 & 70,13 & 72,19 \\
TGT & 71,21 & 72,18 & 74,10 & 72,55 \\
Langsung & 56,54 & 56,67 & 59,72 & 57,53 \\
Rerata Marginal & 63,53 & 67,88 & 68,27 & \\
\hline
\end{tabular}

Karena $\mathrm{H}_{0 \mathrm{~A}}$ ditolak msks diperlukan uji komparasi ganda antar baris dengan hasil sebagai berikut :

Tabel 3. Hasil Uji Komparasi Ganda Antar Baris

\begin{tabular}{ccccc}
\hline No. & \multicolumn{1}{c}{$H_{0}$} & $F_{\text {hitung }}$ & $2 . F_{0,05: 2: n}$ & Keputusan Uji \\
\hline 1 & $\mu_{1 .}=\mu_{2 .}$ & 0,0371 & 6,00 & $H_{0}$ diterima \\
2 & $\mu_{1 .}=\mu_{3 .}$ & 40,0706 & 6,00 & $H_{0}$ ditolak \\
3 & $\mu_{2 .}=\mu_{3}$. & 42,8634 & 6,00 & $H_{0}$ ditolak \\
\hline
\end{tabular}

Berdasarkan tabel 2 rerata masing-masing sel dan Tabel 3 hasil uji komparasi ganda antar baris diperoleh simpulan siswa yang mendapatkan model pembelajaran 
kooperatif tipe TAI memperoleh prestasi belajar yang sama dengan prestasi belajar siswa yang mendapatkan model pembelajaran kooperatif tipe TGT. Siswa dapat memperoleh prestasi yang baik dengan pembelajaran model TAI maupun TGT. Pembelajaran model TAI dan TGT sama-sama dapat merangsang siswa lebih tertarik dalam mengikuti proses belajar mengajar. Dalam pembelajaran model TAI dan TGT siswa lebih aktif dalam proses pembelajaran.

Prestasi belajar siswa yang mendapatkan model pembelajaran kooperatif TAI dan TGT memperoleh prestasi belajar lebih baik dari siswa yang mendapatkan pembelajaran langsung Pada pembelajaran model TAI dan TGT siswa mempunyai ketertarikan yang lebih besar dalam mengikuti proses belajar mengajar dari pembelajaran langsung. Demikian juga dalam hal aktivitas belajar siswa pada pembelajaran model TAI dan TGT lebih tinggi daripada pembelajaran Hasil ini juga bersesuaian dengan penelitian Van Wyk (2012) dalam penelitiannya menunjukkan pembelajaran dengan menggunakan TGT lebih memberikan skor prestasi yang lebih baik dari kelas kontrol.

Dari hasil perhitungan analisis variansi dua jalan dengan sel tak sama diperoleh nilai nilai $F_{a}=26,1655$ lebih besar dari $F_{(0,05 ; 2 ; 24)}=3,00$. Oleh karena itu $H_{0 \mathrm{~A}}$ ditolak, yang berarti terdapat perbedaan rerata antar masing-masing kategori model pembelajaran terhadap prestasi belajar siswa sehingga terdapat perbedaan prestasi belajar yang signifikan antara siswa yang mendapat model pembelajaran kooperatif tipe TAI, model kooperatif tipe TGT, dan pembelajaran langsung.

Berdasarkan hasil uji komparasi ganda antar baris pada masing-masing model pembelajaran, diperoleh simpulan prestasi belajar siswa yang mendapatkan model pembelajaran kooperatif tipe TAI memiliki perbedaan rerata yang tidak signifikan dengan prestasi belajar siswa yang mendapatkan model pembelajaran kooperatif tipe TGT. Hasil ini sesuai dengan hipotesis yaitu siswa yang mendapatkan pembelajaran dengan model TAI memperoleh prestasi yang sama dengan siswa yang mendapat pembelajaran dengan model TGT. Siswa dapat memperoleh prestasi yang baik dengan pembelajaran model TAI maupun TGT. Pembelajaran model TAI mupun TGT dapat memberikan rangsangan terhadap siswa sehingga lebih tertarik dalam mengikuti proses belajar mengajar. Dalam pembelajaran model TAI dan TGT dapat memberikan suasana belajar yang merangsang siswa lebih aktif dalam proses pembelajaran. Dalam pembelajaran TAI siswa dengan kemampuan tinggi membantu siswa dengan kemampuan di bawahnya sehingga semua siswa dapat mencapai prestasi yang maksimal menurut kemampuan mereka masing masing. Individualisasi dipandang penting khususnya pada mata pelajaran matematika, karena dari setiap kemampuan yang diajarkan besar bergantung pada penguasaan 
kemampuan yang dipersyaratkan (Slavin.2011:187). Dalam pembelajaran TGT kompetisi memacu siswa untuk memperoleh skor yang tinggi untuk meningkatkan skor dalam kelompoknya. Siswa dengan kemampuan yang lebih tinggi akan membantu temannya untuk memperoleh skor setinggi mungkin.

Prestasi belajar siswa yang mendapatkan model pembelajaran kooperatif TAI dan TGT memiliki perbedaan rerata secara signifikan dengan prestasi belajar siswa yang mendapatkan pembelajaran langsung, yaitu rerata prestasi belajar siswa yang mendapatkan model pembelajaran kooperatif TAI dan TGT lebih tinggi dari rerata prestasi belajar siswa yang mendapatkan pembelajaran langsung hasil ini bersesuaian dengan hipotesis yang telah dikemukakan, siswa yang mendapatkan pembelajaran dengan model TAI memperoleh prestasi yang sama dengan siswa yang mendapat pembelajaran dengan model TGT. siswa yang mendapat pembelajaran dengan model TAI dan TGT memperoleh prestasi yang lebih baik dari siswa yang mendapat pembelajaran langsung. Pada pembelajaran model TAI dan TGT siswa mempunyai ketertarikan yang lebih besar dalam mengikuti proses belajar mengajar dari pembelajaran langsung. Demikian juga dalam hal aktivitas belajar siswa pada pembelajaran model TAI dan TGT lebih tinggi daripada pembelajaran Hasil ini juga bersesuaian dengan penelitian Van Wyk (2012) dalam penelitiannya menunjukkan pembelajaran dengan menggunakan TGT lebih memberikan skor prestasi yang lebih baik dari kelas kontrol.

Dari hasil perhitungan analisis variansi dua jalan dengan sel tak sama diperoleh nilai $F_{0 \mathrm{~B}}=0,4833$ yang lebih dari nilai $F_{0,05 ; 2 ; 224}=3,00$. Oleh karena itu, $H_{0 \mathrm{~B}}$ diterima, yang berarti tidak terdapat perbedaan prestasi siswa antar masing-masing kategori gaya belajar siswa terhadap prestasi belajar. Siswa dengan gaya belajar Visual, Auditori dan kinestetik memperoleh prestasi belajar yang sama.

Diperoleh hasil siswa dengan gaya belajar visual memperoleh prestasi yang sama dengan siswa dengan gaya belajar auditorial. Hasil ini sesuai dengan hipotesis siswa dengan gaya belajar visual dan auditorial memiliki prestasi belajar yang sama. Hal ini bersesuaian dengan penelitian Akkonyunlu dan Soylu (2008) yang menunjukkan tidak terdapat perbedaan yang signifikan antara tingkat preatasi sesuai dengan gaya belajarnya. Siswa dengan gaya belajar visual dapat belajar dengan baik dengan membaca materi yang disampaikan guru di papan tulis maupun membaca dari berbagai sumber yang ada. Penggunaan media pembelajaran yang membantu siswa dengan gaya belajar visual karena memudahkan mereka menerima informasi yang nampak/dapat dibaca dengan kelas. Penggunaan LKS dapat meningkatkan kemampuan siswa dengan gaya belajar visual yang dapat belajar dengan baik dengan membaca. Siswa dengan gaya belajar 
auditorial memiliki modalitas indrawi dengan mendengarkan, berbicara/berdiskusi, bicara sendiri/dialog batin. Siswa dengan gaya belajar auditorial mendengarkan penjelasan dari guru untuk menerima informasi dalam pembelajaran. Diskusi dengan teman juga membantu siswa dalam menyerap informasi dengan baik. Siswa dengan gaya belajar auditorial kadang-kadang juga berbicara sendiri untuk mengingat informasi yang mereka dapat, hal ini dapat mereka lakukan dalam pembelajaran.

Terdapat perbedaan hasil penelitian dengan hipotesis yang diajukan di depan. Siswa dengan gaya belajar visual, auditorial, dan kinestetik memperoleh prestasi belajar yang sama hal ini berbeda dengan hipotesis kedua yaitu siswa dengan gaya belajar visual dan auditori memilki prestasi yang lebih baik dari siswa dengan gaya belajar kinestetik. Siswa dengan gaya belajar visual dan auditorial memiliki prestasi belajar yang sama. Hal ini terjadi mungkin disebabkan pada siswa dengan gaya belajar kinestetik memiliki motivasi belajar yang baik sehingga dapat memperoleh prestasi belajar yang sama dengan gaya belajar yang lain.

Pada masing-masing pembelajaran kooperatif tipe TAI, pembelajaran kooperatif tipe TGT dan pembelajaran langsung siswa yang memiliki gaya belajar visual, auditori, dan kinestetik memperoleh prestasi yang sama.

Hal ini sesuai dengan hipotesis yang dirumuskan pada penelitian ini, hal ini juga bersesuaian dengan penelitian Akkoyunlu dan Soylu (2008) yang memberikan hasil tidak terdapat perbedaan yang signifikan tingkat prestasi belajar siswa menurut gaya belajarnya pada pembelajaran dengan menggunakan media. Pada pembelajaran model TAI siswa yang memiliki gaya belajar visual, auditorial, dan kinestetik memperoleh prestasi yang sama. Siswa dengan gaya belajar visual yang membutuhkan gambar maupun alat peraga mendapatkan dalam penyajian media pembelajaran, siswa juga dapat belajar dengan baik dengan membaca dapat dilakukan pada pembelajaran. Siswa Auditorial dapat mendengarkan penjelasan dari guru pada saat penyajian kelas, juga dapat mendengarkan dari teman dalam satu kelompok pada saat diskusi kelompok. Siswa dengan gaya belajar kinestetik yang belajar disetai dengan gerakan atau aksi mereka dapat belajar dengan baik pada saat diskusi kelompok. Dengan bimbingan dari teman satu kelompok yang duduk di sampingnya saat diskusi kelompok juga membantu siswa dengan gaya belajar kinestetik.

Pada pembelajaran TGT siswa yang memiliki gaya belajar visual, auditorial, dan Kinestetik memperoleh prestasi yang sama. Hal ini sesuai dengan hipotesis yang dirumuskan pada penelitian ini, hal ini juga bersesuaian dengan penelitian Akkoyunlu dan Soylu (2008) yang memberikan hasil tidak terdapat perbedaan yang signifikan tingkat prestasi belajar siswa menurut gaya belajarnya. Pada pembelajaran TGT siswa dengan 
gaya belajar visual dapat belajar dengan baik. Siswa dengan gaya belajar visual mengandalkan penglihatan dalam belajar. Dengan melihat media pembelajaran yang ditayangkan guru maupun dengan menuliskan hasil diskusi mereka siswa dengan gaya belajar. Siswa dengan gaya belajar auditori mengandalkan pendengaran dalam belajar. Dengan mendengarkan penjelasan guru dalam penyajian kelas dan mendengarkan penjelasan dari teman dalam satu kelompok membantu siswa dalam belajar. Siswa dengan gaya belajar kinestetik lebih baik dalam menangkap materi pemeblajaran jika berbicara secara pribadi, hal ini didapatkan siswa dalam diskusi kelompok. Belajar dengan tahapan selangkah demi selangkah juga dapat dilaksanakan dengan bantuan teman dalam satu kelompok. Siswa dengan masing-masing gaya belajar visual, auditorial, dan kinestetik lebih besar da lam usaha belajarnya untuk bersaing dengan kelompok lain

Pada pembelajaran langsung siswa yang masing-masing memiliki gaya belajar visual memperoleh prestasi yang sama dengan siswa dengan gaya belajar auditorial. Hasil ini sesuai dengan hipotesis. Pada pembelajaran langsung siswa dengan gaya belajar visual hanya belajar dengan membaca dari buku yang disediakan. Demikian pula siswa dengan gaya belajar auditorial belajar dari penjelasan guru secara lisan.

Pada pembelajaran langsung siswa yang masing-masing memiliki gaya belajar visual memperoleh prestasi yang sama dengan siswa dengan gaya belajar kinestetik. Terdapat perbedaan dengan hipotesis yang telah dirumuskan yaitu pada pembelajaran langsung siswa dengan gaya belajar visual memperoleh prestasi belajar yang lebih baik dari siswa dengan gaya belajar kinestetik. Hal ini mungkin siswa dengan gaya belajar visual kurang dapat memaksimalkan belajar mereka yang mengandalkan penglihatan.

Pada pembelajaran langsung siswa yang masing-masing memiliki gaya belajar auditorial memperoleh prestasi yang sama dengan siswa dengan gaya belajar Kinestetik. Terdapat perbedaan dengan hipotesis yang telah dirumuskan yaitu pada pembelajaran langsung siswa dengan gaya belajar auditorial memperoleh prestasi belajar yang lebih baik dari siswa dengan gaya belajar kinestetik. Hal ini mungkin terjadi karena siswa dengan gaya belajar auditorial kurang dapat memaksimalkan belajar mereka karena hanya mendengarkan dari penjelasan guru saja.

Dari hasil perhitungan bahwa tidak terdapat interaksi antara model pembelajaran dengan gaya belajar. Siswa dengan masing-masing gaya belajar visual, auditorial dan kinestetik, yang medapat pembelajaran dengan model TAI dan TGT memperoleh prestasi belajar yang lebih baik dari siswa yang mendapatkan pembelajaran langsung. Siswa dengan masing-masing gaya belajar visual, auditorial, dan kinestetik, yang medapat 
pembelajaran dengan model TAI memperoleh prestasi belajar yang sama dengan siswa yang mendapatkan pembelajaran dengan model TGT.

Terdapat perbedaan dengan hipotesis yang dirumuskan yaitu siswa dengan masing-masing gaya belajar visual dan auditori yang memperoleh pembelajaran dengan model TAI memperoleh prestasi belajar yang sama dengan siswa yang mendapat pembelajaran dengan model TGT dan pembelajaran langsung. Pada peneliatian ini siswa dengan masing-masing gaya belajar visual dan auditori yang memperoleh pembelajaran dengan model TAI dan TGT memperoleh prestasi belajar yang lebih baik dari siswa yang memperoleh pembelajaran langsung. Hal ini mungkin disebabkan siswa jarang mendapatkan pembelajaran kooperatif sehingga siswa mendapatkan suasana belajar yang baru yang dapat meningkatkan minat dan motivasi belajar yang lebih dari siswa yang mendapatkan pembelajaran langsung.

Diperoleh hasil yang sesuai dengan hipotesis yang telah dirumuskan yaitu Siswa dengan gaya belajar kinestetik yang medapat pembelajaran dengan model TAI dan TGT memperoleh prestasi belajar yang lebih baik dari siswa yang mendapatkan pembelajaran langsung. Siswa dengan masing-masing gaya belajar kinestetik yang mendapat pembelajaran dengan model TAI memperoleh prestasi belajar yang yama dengan siswa yang mendapatkan pembelajaran dengan model TGT. Hal ini bersesuaian dengan penelitian Reza Kusuma (2012) yang memberikan hasil pembelajaran TAI memberikan hasil belajar yang lebih baik, juga bersesuaian dengan penelitian Bette $\mathrm{C}$ dan Phillip $\mathrm{C}$ (1991) yaitu pembelajaran dengan model TGT memberikan hasil yang lebih baik secara signifikan terkait dengan prestasi.

\section{SIMPULAN DAN SARAN}

Berdasarkan hasil analisis dan pembahasan terhadap uji hipotesis serta mengacu pada rumusan masalah yang telah dirumuskan pada penelitian ini, maka dapat disimpulkan bahwa:

Model pembelajaran TAI memberikan prestas belajar yang sama dengan model pembelajaran TGT, model pembelajaran TAI memberikan prestasi belajar yang lebih baik dari pembelajaran langsung, demikian pula model pembelajran TGT juga meberikan prestasi yang lebih baik dari pembelajaran langsung. Siswa yang memiliki gaya belajar Visual, Auditorial, dan Kinestetik mempunyai prestasi belajar yang sama

Pada pembelajaran dengah model TAI siswa dengan gaya belajar Visual, Auditori, dan Kinestetik mempunyai prestasi belajar yang sama. Pada pembelajaran dengah model TGT siswa dengan gaya belajar Visual, Auditori, dan Kinestetik 
mempunyai prestasi belajar yang sama. Pada pembelajaran langsug siswa dengan gaya belajar Visual, Auditori, dan Kinestetik mempunyai prestasi belajar yang sama

Siswa dengan gaya belajar Visual model pembelajaran TAI memberikan prestas belajar yang sama dengan baik dengan model pembelajaran TGT, model pembelajaran TAI memberikan prestasi belajar yang lebih baik dari pembelajaran langsung, demikian pula model pembelajran TGT juga meberikan prestasi yang lebih baik dari pembelajaran langsung. Siswa dengan gaya belajar Auditori model pembelajaran TAI memberikan prestas belajar yang sama dengan baik dengan model pembelajaran TGT, model pembelajaran TAI memberikan prestasi belajar yang lebih baik dari pembelajaran langsung, demikian pula model pembelajran TGT juga meberikan prestasi yang lebih baik dari pembelajaran langsung. Siswa dengan gaya belajar Kinestetik model pembelajaran TAI memberikan prestas belajar yang sama dengan baik dengan model pembelajaran TGT, model pembelajaran TAI memberikan prestasi belajar yang lebih baik dari pembelajaran langsung, demikian pula model pembelajran TGT juga meberikan prestasi yang lebih baik dari pembelajaran langsung.

Berdasarkan hasil penelitian penulis memberikan saran sebagai berikut : Dalam pelaksanaan pembelajaran menggunakan model TAI maupun TGT kepala sekolah hendaknya berperan aktif dalam memberikan ide, motivasi, dan menyediakan sarana dan prasarana agar siswa dapat bekerja secara berkelompok dengan lebih efektif dan terstruktur. Memperhatikan hasil penelitian ini, model pembelajaran TAI dan TGT layak digunakan dalam pembelajaran matematika khususnya pada materi lingkaran. Kedua tipe model kooperatif tersebut terbukti mampu meningkat meningkatkan hasil belajar siswa. Melihat hal ini, sangat disarankan guru mau menggunakan salah satu dari dua model tersebut dalam pembelajaran matematika guna meningkatkan prestasi belajar para siswa, baik siswa dengan kemampuan tinggi, kemampuan sedang, maupun yang berkemampuan dibawah yang lain. Guru sebaiknya dalam proses belajar mengajar menggunakan kegiatan yang dapat mengakomodasi gaya belajar siswa. Siswa hendaknya mempererat hubungan antar siswa baik dalam pembelajaran maupun di luar pembelajaran. Hubungan yang baik antar siswa akan menumbuhkan kerjasama yang lebih baik dalam diskusi kelompok maupun dalam diskusi kelas. Siswa yang lebih unggul dalam prestasi harus membantu teman yang kesulitan memahami suatu materi. Bagi para peneliti, tesis ini dapat digunakan sebagai acuan atau referensi untuk melakukan penelitian yang lain. Diharapkan para peneliti dapat mengembangkan penelitian untuk model pembelajaran TAI dan TGT untuk meningkatkan prestasi belajar siswa. Bagi peneliti yang ingin 
meneliti prestasi siswa yang berhubungan dengan gaya belajar siswa, merencanakan angket gaya belajar dengan lebih baik.

\section{DAFTAR PUSTAKA}

Akkoyunlu, B. \& Soylu, M. Y. 2008. A study of Student's Perceptios in A Blended Learning Environment Based on Different Learning Styles. Journal Educational Technology \& Society, 11(1): 183-193

Bette, C \& Philip, A. C. 1991. The relationship between student team learning outcomes and achievement, causal attributions, and affect. Journal of Educational Psychology, 83(1): 140-146

Budiyono. 2009. Statistika Untuk Penelitian, Surakarta: UNS Press.

De Potter.B. \& Hernacki.M. 2012. Quantum Learning, Bandung : Kaifa Learning

Reza Kusuma Setyansyah. 2012. "Efektifitas Model Pembelajaran Kooperatif tipe Team Assisted Individualization (TAI) dan Group Investigation (GI) ditinjau dari konsep diri siswa., dglib.uns.ac.id

Tarim, K \& Akdeniz, F. 2008. The Effects of Cooperative Learning on Turkish Elementary Students' Mathematics Achievement and Attitude Towards Mathematics Using TAI and STAD Methods. Educ. Stud. Math. 67(1): 77-91.

Veloo, A \& Sitie, C. 2013. Fostering students' attitudes and achievement in probability using teams-games-tournaments. Procedia - Social and Behavioral Sciences 93(1) $59-64$

Wyk, M. M. V. 2011. The Effects of Teams-Games-Tournaments on Achievement, Retention, and Attitudes of Economics Education Students. Journal of Social Science, 26(3): 183-193. 